\title{
Kesalahan siswa kelas VIII SMP Negeri 13 Mataram dalam menyelesaikan soal cerita materi sistem persamaan linear dua variabel tahun pelajaran 2019/2020
}

\author{
Rangga Faradisha ${ }^{*}$, Hj. Sripatmi ${ }^{2}$, Eka Kurniawan ${ }^{2}$, Nani \\ Kurniati $^{2}$
}

\author{
${ }^{1}$ Mahasiswa Pendidikan Matematika, FKIP, Universitas Mataram, Mataram \\ ${ }_{2}^{2}$ Pendidikan Matematika, FKIP, Universitas Mataram, Mataram
}

ranggafrdsha@gmail.com

Diterima: 17-10-2021; Direvisi: 26-10-2021, Dipublikasi: 30-10-2021

\begin{abstract}
The Errors made by students in completed math problems can be indicators of low learning achievements. Based on these problems, this study aims to know the categories of errors and the relation or correlations of the types of errors each Polya's steps in solving the material story of system two linear equations students all grade VIII of SMP Negeri 13 Mataram academic year 2019/2020. The population in this study was all students grade VIII of SMP Negeri 13 Mataram. Samples used the Proportionate Stratified Random Sampling technique. Data collection used test essay and interview which had beenvalidated. Error categories were analyzed used interval categories of error levels and for the relation or correlations between types of errors using the Pearson product-moment correlation was. The results showed that students mistake for high abilities in the low category, for the medium abilities in the high category and the low ability level in the high category. Based on data analysis it was found three categories of relationships types of errors : namely, sufficient, strong and very strong categories. The level of relationship is strong enough for this type of error to understand the problem and formulate a plan, misunderstanding the problem and carrying out the plan, misunderstanding the problem and re-checking. Level of strong links to types of mistakes Arranging plans and executing plans, mistakes compiling plans and re-checking. The level relationship is very strong for type error implementing the plan by checking again. When completed a problem should be solved systematically in stages to avoid mistakes that will be made at a later stage.
\end{abstract}

Keywords: error; material story; System Two Linear Equations

\begin{abstract}
Abstrak
Kesalahan-kesalahan yang dilakukan oleh peserta didik dalam menyelesaiakan soal matematika dapat menjadi indikator rendahnya hasil belajar peserta didik. Berdasarkan masalah tersebut dilakukan penelitian dengan tujuan untuk mengetahui kategori kesalahan dan hubungan atau korelasi jenis-jenis kesalahan masing-masing langkah Polya dalam menyelesaikan soal cerita materi sistem persamaan linier dua variabel berdasarkan tingkat kemampuan siswa kelas VIII SMP Negeri 13 Mataram tahun pelajaran 2019/2020. Populasi dalam penelitian ini adalah seluruh kelas VIII SMP Negeri 13 Mataram. Sampel dipilih dengan menggunakan teknik Proportionate Stratified Random Sampling. Pengumpulan data dilakukan dengan menggunakan tes tulis yang berupa soal uraian dan wawancara yang sudah divalidasi. Kategori kesalahan dianalisis menggunakan interval kategori tingkat kesalahan sedangkan untuk hubungan antara jenis-jenis kesalahan menggunakan uji korelasi pearson product moment. Hasil penelitian menunjukan kesalahan siswa untuk tingkat kemampuan tinggi berkategori rendah, untuk tingkat kemampuan sedang berkategori tinggi dan untuk tingkat kemampuan rendah berkategori tinggi. Berdasarkan analisis data, ditemukan tiga kategori hubungan jenis kesalahan yaitu kategori cukup, kuat dan sangat kuat. Tingkat hubungan cukup kuat untuk jenis kesalahan memahami masalah dan menyusun rencana, kesalahan memahami masalah dan melaksanakan rencana, kesalahan memahami masalah dan melakukan pengecekan kembali. Tingkat hubungan kuat untuk jenis kesalahan menyusun rencana dan melaksanakan rencana, kesalahan
\end{abstract}


menyusun rencana dan melakukan pengecekan kembali. Tingkat hubungan sangat kuat untuk jenis kesalahan melaksanakan rencana dengan melakukan pengecekan kembali. Pada saat menyelesaiakan soal cerita sebaiknya menyelesaikan dengan sistematis secara bertahap untuk menghindari kesalahan yang akan dilakukan pada tahap selanjutnya.

Kata Kunci: kesalahan; soal cerita; Sistem Persamaan Linier Dua Variabel

\section{PENDAHULUAN}

Pencapaian mata pelajaran matematika dalam Ujian Nasional tahun pelajaran 2018/2019 jenjang SMP masih rendah dibandingkan dengan mata pelajaran lain yaitu rata-rata nilai mata pelajaran matematika 46,561, mata pelajaran bahasa indonesia 65,689, mata pelajaran bahasa inggris 50,23, mata pelajaran IPA 48,794 (Pusat Penilaian Pendidikan Kementerian Pendidikan dan Kebudayaan, 2019) .

Rendahnya pemahaman siswa dalam mata pelajaran matematika juga terjadi di SMPN 13 Mataram. Rata-rata dan presentase ketuntasan klasikal tergolong rendah dari kriteria yang ditetapkan oleh sekolah yaitu 75 untuk mata pelajaran matematika Hal ini dapat diketahui dari hasil penilaian akhir semester ganjil tahun pelajaran 2018/2019. Rata-rata nilai dan presentase ketuntasan klasikal siswa SMP Negeri 13 Mataram Semester Ganjil Tahun Pelajaran 2018/2019 berturut-turut adalah 68,84 dan $27,26 \%$.

Rendahnya pemahaman matematika siswa tak luput dari pola kesalahan umum yang dilakukan siswa dalam menyelesaikan soal-soal matematika. Kesalahankesalahan ini akan terlihat setelah siswa menyelesaikan soal matematika. Dengan melihat pekerjaan siswa maka dapat dideteksi jenis kesalahan yang berhubungan dengan bahasa, kesulitan informasi, menguasai fakta dan konsep, menerjemahkan masalah matematika yang relevan.

Salah satu pembelajaran matematika yang dapat mengasah kemampuan berpikir logis, analisis, sistematis, kritis dan kreatif dengan menyajikan soal matematika dalam bentuk soal cerita. Soal matematika berbentuk soal cerita membutuhkan kefokusan dan ketelitian yang tinggi dalam pengerjaannya.

Pada pengerjaan soal cerita, soal perlu terlebih dahulu dianalisis sebelum membuat rencana penyelesaian dan penyelesaiannya. Setelah soal dianalisis, perlu dilakukan penerjemahan soal cerita kedalam model matematika. Saat siswa diberikan soal matematika dalam bentuk soal cerita seringkali siswa merasa kesulitan untuk menerjemahkan soal cerita tersebut, sehingga memperoleh nilai yang kurang maksimal (Tabondo, Y.V. dan Sinaga, Y.R., 2014). Selain itu kesulitan terlihat dari bagaimana siswa menyelesaikan soal cerita. Terkadang, ketika dihadapkan dengan soal matematika yang dirumuskan secara matematis, siswa dapat menjawab dengan benar dan tidak makan waktu yang lama, tetapi ketika soal yang sama disajikan dalam bentuk cerita, siswa sering kesulitan dalam menyelesaikannya, dan ketika selesai pun belum tentu jawabannya benar.

Berdasarkan hasil wawancara pada guru matematika kelas VIII yang bernama Aminah Endang Astuti, S.Pd. pada hari Rabu tanggal 22 Mei 2019 didapatkan hasil 
bahwa masih banyak kendala-kendala siswa dalam mengerjakan soal cerita matematika. Kendala utama yang dialami siswa adalah rendahnya kemampuan siswa dalam memahami maksud dari soal cerita yang telah diberikan, Rendahnya kemampuan siswa dalam memahami maksud dari soal cerita akan berdampak pada proses pengerjaannya dimana siswa memilih tidak melanjutkan untuk menyelesaikan soal cerita yang diberikan. Kendala lainnya yang dapat dilihat oleh peneliti adalah ketika siswa sudah diarahkan dan mengerti maksud soal.

Untuk menyelesaikan soal dalam bentuk soal cerita dapat digunakan berbagai prosedur, salah satunya adalah dengan menggunakan Prosedur Polya. Menurut Polya untuk menyelesaikan masalah matematika siswa harus melalui beberapa tahapan mulai dari memahami masalah, menyusun rencana, melaksanakan rencana, sampai melakukan pengecekan kembali pada jawaban yang sudah didapatkan (Hidayah, Shofia, 2016). Pada prosedur Polya tahapan-tahapan pemecahan masalah tersusun secara sisematis dengan tingkat keterkaitan tiap tahapan berbeda-beda.

Berdasarkan permasalahan di atas, penulis termotivasi melakukan penelitian dengan judul "Kesalahan siswa kelas VIII SMPN 13 Mataram dalam Menyelesaikan Soal Cerita Materi Sistem Persamaan Linear Dua Variabel Tahun Pelajaran 2019/2020". Tujuan penelitian ini adalah untuk mengetahui kategori kesalahan siswa kelas VIII SMP Negeri 13 Mataram dalam menyelesaikan soal cerita materi sistem persamaan linier dua variabel berdasarkan tingkat kemampuan tahun pelajaran 2019/2020 dan untuk mengetahui hubungan atau korelasi jenis-jenis kesalahan masing-masing langkah Polya dalam menyelesaikan soal cerita materi sistem persamaan linier dua variabel berdasarkan tingkat kemampuan siswa kelas VIII SMP Negeri 13 Mataram tahun pelajaran 2019/2020.

\section{METODE PENELITIAN}

Jenis penelitian yang digunakan adalah penelitian kualitatif dengan metode deskriptif. Penelitian ini dilakukan pada semester genap tahun pelajaran 2019/2020 dan dilaksanakan di kelas VIII SMP Negeri 13 Mataram.

Populasi dalam penelitian ini adalah seluruh siswa kelas VIII SMP Negeri 13 Mataram tahun pelajaran 2019/2020 yang berjumlah 275 orang. Sebelumnya siswa dikelompokkan berdasarkan prestasi belajar. Teknik pengambilan sampel dengan menggunakan Proportionate Stratified Random Sampling. Pengambilan sampel untuk penelitian ini adalah $20 \%$ dari populasi berdasarkan tingkat kemampuan.

Metode pengumpulan data dengan menggunakan tes dan wawancara. Tes ini diberikan untuk memperoleh data kategori kesalahan siswa dalam menyelesaikan soal cerita dan korelasi setiap langkah Polya. siswa diberikan tes berbentuk uraian sebanyak tiga soal cerita yang dikerjakan dalam waktu 60 menit.. Wawancara dilakukan dengan tujuan untuk mengetahui dan menangkap secara langsung seluruh informasi dari subjek penelitian. Materi wawancara berisi kendala-kendala yang dihadapi siswa dalam mengerjakn tes yang sesuai dengan keadaan di lapangan 
yang tidak diikat oleh pedoman tertentu. Sebelum digunakan istrumen tes terlebih dahulu diuji validitasnya dengan menggunakan validitas konstruk. Validitas konstruk dalam hal ini divalidasi oleh dosen ahli dan guru ahli bidang mata pelajaran matematika .

Teknik Analisis data dalam penelitian ini dilakukan Analisis data dilakukan dengan menggunakan teknik analisis data deskriptif kualitatif model Miles and Huberman dengan tahapan-tahapan sebagai berikut.

\section{Data Reduction ( Reduksi Data )}

Reduksi data dalam penelitian ini dilakukan untuk mengidentifikasi bentuk-bentuk kesalahan siswa pada tahapan pemecahan masalah matematika berdasarkan hasil pekerjaan siswa yang salah. Hasil pekerjaan siswa diperiksa dan dikelompokkan menjadi dua yaitu jawaban yang benar dan jawaban yang salah. Jawaban yang salah akan dianalisa lebih lanjut untuk diidentifikasi bentuk-bentuk kesalahan yang dilakukan pada masing-masing tahapan pemecahan masalah menurut Polya dengan menggunakan indikator yang telah dirumuskan Untuk mencari kategori kesalahan dalam menyelesaikan soal cerita, akan dilakukan analisis tingkat kesalahan dengan menggunakan $M_{i}($ Mean Ideal $)$ dan $S D_{i}($ Standar Deviasi Ideal $)$.

$$
\begin{gathered}
M_{i}=\frac{1}{2} \times(\text { skor terting } i+\text { skor terendah }) \\
S D_{i}=\frac{1}{3} \times M_{i}
\end{gathered}
$$

Setelah didapatkan kriteria tingkat kesalahan kemudian menentukan hubungan atau korelasi antara jenis-jenis kesalahan yang dilakukan dapat digunakan analisis data uji pearson product moment atau analisis korelasi.

$$
r_{X_{i} X_{j}}=\frac{n\left(\sum X_{i} X_{j}\right)-\left(\sum X_{i}\right) \cdot\left(\sum X_{j}\right)}{\sqrt{\left\{n \cdot \sum X_{i}^{2}\right\} \cdot\left\{n \cdot \sum X_{j}^{2}-\left(\sum X_{j}\right)^{2}\right\}}}
$$

Sedangkan untuk menyatakan besar kecilnya sumbangan variabel $X_{i}$ dan $X_{j}$ dapat ditentukan dengan rumus koefisien determinan sebagai berikut.

$$
K P=r^{2} \times 100 \%
$$

\section{Data Display ( Penyajian Data )}

Dalam penelitian ini data yang telah diperoleh akan disajikan dalam bentuk tabel. Tabel tersebut menyajikan kategori kesalahan siswa dan hubungan atau korelasi langkah Polya.

\section{Conclusion Drawing/Verification}


Dengan membaca data yang telah disajikan maka dapat ditarik kesimpulan mengenai kategori kesalahan siswa berdasarkan tahapan pemecahan masalah Polya dan hubungan atau korelasi masing-masing langkah Polya

\section{HASIL DAN PEMBAHASAN}

\subsection{Hasil Penelitian}

Penelitian ini dilakukan untuk mengetahui kategori kesalahan siswa dan hubungan atau korelasi masing-masing langkah Polya dalam menyelesaikan soal cerita materi sistem persamaan linier dua variabel berdasarkan tingkat kemampuan siswa kelas VIII SMP Negeri 13 Mataram tahun pelajaran 2019/2020. Siswa yang diteliti berjumlah 55 siswa dengan 15 siswa dengan kemmapuan tinggi, 20 siswa dengan kemampuan sedang dan 20 siswa dengan kemampuan rendah. Penelitian ini dilaksanakan pada tanggal 23-27 Januari 2020 di SMP Negeri 13 Mataram. Tes tulis dilaksanakan pada hari kamis tanggal 23 januari 2020 dimulai dari pukul 08.00-09.00 wita. Wawancara dilaksanakan pada hari Jumat tanggal 24 Januari 2020 pada pukul 09.30-10.00 wita dan dilanjutkan pada hari Senin tanggal 27 Januari 2020 pada pukul 10.10-12.40 wita. Data dalam penelitian ini berupa tes uraian soal cerita materi sistem persamaan linier dua variabel dan wawancara.

Instrumen yang digunakan dalam penelitian ini berupa soal tertulis dan wawancara. Wawancara yang digunakan adalah wawancara bebas sesuai dengan keadaan dilapangan yang tidak diikat oleh pedoman tertentu. Soal tes tertulis sebelum digunakan divalidasi oleh ahli, yaitu ibu Nani Kurniati, S.Pd.,M.Sc. dan ibu Aminah Endang Asuti, S.Pd. selaku dosen pendidikan matematika di Universitas Mataram dan guru program studi matematika di SMP Negeri 13 Mataram. Dari hasil validasi didapatkan hasil bahwa instrument tersebut layak digunakan dengan perbaikan dan layak digunakan. Instrument yang diuji adalah instrument yang dirancang oleh peneliti dengan menyesuaikan kompetendi dasar dan indikator pada materi sistem persamaan linier dua variabel (SPLDV).

Berdasarkan hasil analisis skor dari kesalahan siswa kelas VIII SMP Negeri 13 Mataram dengan mengacu pada pedoman penskoran. Diperoleh hasil dalam bentuk diagram pada Gambar 1. 


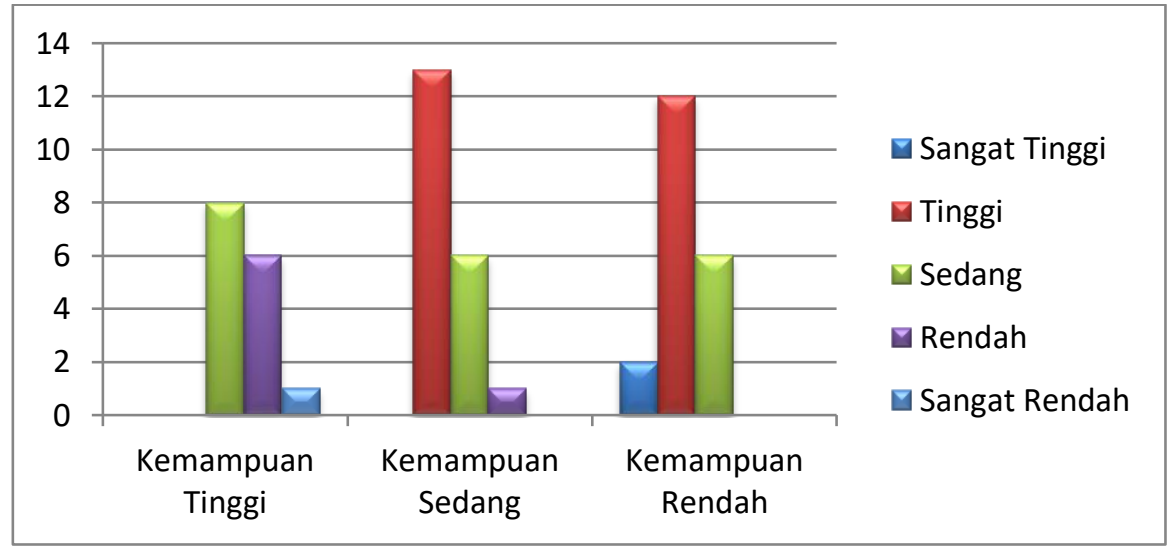

Gambar 1. Hasil analisis skor dari kesalahan siswa

Selanjutnya hasil analisis deskripsi data tingkat kesalahan siswa untuk seluruh tingkat kemampuan dalam bentuk diagram disajikan pada Gambar 2.

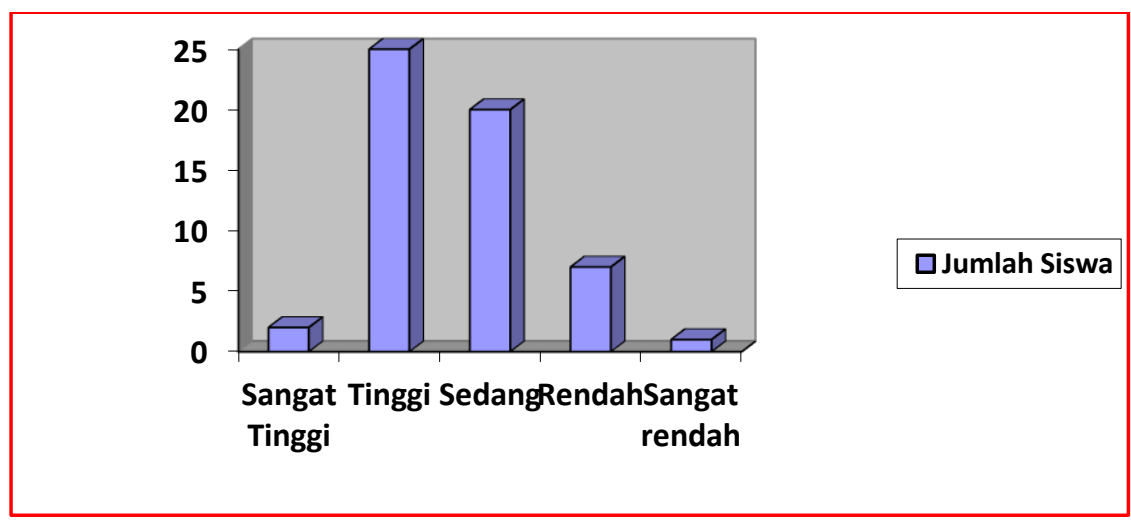

Gambar 2. Analisis deskripsi data kategori tingkat kesalahan

Hasil yang diperoleh dari uji korelasi pearson product moment dapat dilihat pada Tabel 1.

Tabel 1. Hasil uji korelasi pearson product moment

\begin{tabular}{|c|c|c|c|c|}
\hline & $\mathrm{X} 1$ & $\mathrm{X} 2$ & $\mathrm{X} 3$ & $\mathrm{X} 4$ \\
\hline X1 & 1 & & & \\
\hline $\mathrm{X} 2$ & 0,55 & 1 & & \\
\hline X3 & 0,49 & 0,79 & 1 & \\
\hline $\mathrm{X} 4$ & 0,49 & 0,69 & 0,84 & 1 \\
\hline
\end{tabular}

Hasil korelasi pearson product moment, tingkat hubungan dan hubungganya dapat dilihat pada table 2 berikut 
Tabel 2. Hasil korelasi pearson product moment, tingkat hubungan dan hubungannya

\begin{tabular}{|c|c|c|c|c|}
\hline Korelasi & $\mathbf{R}$ & $\begin{array}{c}\text { Koefisien } \\
\text { Penentu }\end{array}$ & $\begin{array}{l}\text { Tingkat } \\
\text { Hubungan }\end{array}$ & Hubungan \\
\hline $\mathrm{X} 1$ dan $\mathrm{X} 2$ & 0,55 & $30,57 \%$ & Cukup & $\begin{array}{l}\text { Ada hubungan yang cukup } \\
\text { kuat antara X1 dan X2 }\end{array}$ \\
\hline $\mathrm{X} 1 \operatorname{dan} \mathrm{X} 3$ & 0,49 & $24,50 \%$ & Cukup & $\begin{array}{l}\text { Ada hubungan yang cukup } \\
\text { kuat antara X1 dan X3 }\end{array}$ \\
\hline X1dan X4 & 0,49 & $24,67 \%$ & Cukup & $\begin{array}{l}\text { Ada hubungan yang cukup } \\
\text { kuat antara X1 dan X4 }\end{array}$ \\
\hline $\mathrm{X} 2 \operatorname{dan} \mathrm{X} 3$ & 0,79 & $63,56 \%$ & Kuat & $\begin{array}{l}\text { Ada hubungan yang kuat } \\
\text { antara X2 dan X3 }\end{array}$ \\
\hline $\mathrm{X} 2 \operatorname{dan} \mathrm{X} 4$ & 0,69 & $47,88 \%$ & Kuat & $\begin{array}{l}\text { Ada hubungan yang kuat } \\
\text { antara X2 dan X4 }\end{array}$ \\
\hline $\mathrm{X} 3 \operatorname{dan} \mathrm{X} 4$ & 0,84 & $70,76 \%$ & $\begin{array}{l}\text { Sangat } \\
\text { Kuat }\end{array}$ & $\begin{array}{l}\text { Ada hubungan yang sangat } \\
\text { kuat antara X3 dan X4 }\end{array}$ \\
\hline
\end{tabular}

\subsection{Pembahasan}

Berdasarkan hasil pekerjaan subjek penelitian yang telah diuraikan dapat dilihat bahwa sebagian besar subjek penelitian dalam menyelesaikan masalah yang terkait dengan materi SPLDV melakukan kesalahan pada semua tahapan pemecahan masalah. Kesalahan-kesalahan tersebut adalah kesalahan memahami masalah, kesalahan menyusun rencana, kesalahan melaksanakan rencana, dan kesalahan melakukan pengecekan kembali. Hal ini menyebabkan siswa kesulitan untuk dapat menyelesaikan soal cerita khususnya materi sistem persamaan linier dua variabel (SPLDV).

\subsubsection{Analisis Kesalahan Siswa Tingkat kemampuan Tinggi}

\section{Subjek A5}

Subjek A5 memperoleh kategori tingkat kesalahan rendah dengan jumlah skor kesalahan 23. Siswa mampu menjawab semua soal yang diberikan. Berdasarkan hasil pekerjaan subjek A5, siswa tidak memangalami kesalahan dalam tahap memahami masalah, siswa sudah tepat menuliskan apa yang diketahui dan apa yang ditanyakan dalam soal. Pada tahap menyusun rencana siswa sudah menuliskan permisalan variabel walaupun belum tepat. siswa juga sudah mampu membuat model matematika sesuai dengan apa yang diketahui dan ditanyakan dalam soal namun pada tahap menyususun rencana siswa tidak konsisten menuliskan metode apa yang digunakan dan bagaimana langkah-langkah penyelesaian. Pada tahap melaksanakan rencana peneliti tidak mengetahui apakah siswa menyelesaikan soal sesuai dengan langkah-langkah yang telah dipilih, namun berdasarkan hasil wawancara siswa menyelesaikan soal dengan metode dan langkah-langkah yang telah dipilih tetapi siswa tidak menuliskan pada lembar jawaban yang telah diberikan. Pada saat melakukan perhitungan siswa melakukan perhitungan dengan benar dan runtut, siswa memperoleh jawaban akhir namun siswa tidak konsisten menuliskan kesimpulan dari jawaban yang diperoleh Pada 
tahap melakukan pengecekan kembali, siswa sudah mampu melakukan tahap ini tetapi untuk soal nomor 1 siswa salah dalam melakukan.

Siswa dengan tingkat kemampuan tinggi sering sekali melakukan kesalahan membuat permisalan menggunakan variabel dalam menyusun model matematika. Kesalah pahaman siswa yang berkaitan dengan konsep variabel diantaranya: huruf sebagai label dan kurang memahami variabel sebagai sesuatu yang belum diketahui nilainya, kurang memahami variabel sebagai generalisasi bilangan. siswa dengan tingkat kemampuan tinggi mempunyai kemampuan lebih baik dalam melaksanakan penyelesaian daripada siswa yang lain, hal ini disebabkan karena siswa berkemampuan tinggi lebih memahami konsep SPLDV (Herutomo, Rezky A, 2014). Siswa dengan tingkat kemampuan tinggi tidak mengalami kesulitan dalam memahami masalah. Subjek dengan kecerdasan logis matematis tinggi mampu memahami masalah dengan baik (Mahardhikawati, Ema., Mardiyana dan Rubono S, 2017).

\section{Subjek D16}

Subjek D16 memperoleh kategori tingkat kesalahan sangat rendah dengan jumlah skor kesalahan 18. Siswa mampu menjawab semua soal yang diberikan. Kesalahan yang dilakukan oleh subjek D16 hampir sama dengan kesalahan yang dilakukan oleh subjek A5 yaitu pada tahap memahami masalah, siswa sudah tepat menuliskan apa yang diketahui dan apa yang ditanyakan dalam soal. Pada tahap menyusun rencana siswa menuliskan permisalan variabel walaupun belum tepat untuk soal nomor. Siswa tidak menuliskan model matematika untuk soal nomor 1 tetapi siswa dapat melanjutkan tahap berikutnya. Siswa menuliskan metode dan langkah-langkah yang digunakan dalam menyelesaikan soal yang diberikan tetapi siswa belum konsisten menuliskan. Pada tahap melaksanakan rencana siswa menyelesaiakan soal sesuai dengan metode yang dipilih. Siswa melakukan perhitungan dengan runtut dan benar dan menuliskan kesimpulan akhir dari soal nomor 1. Pada tahap melakukan pengecekan kembali, siswa tidak melakukan pengecekan kembali hanya untuk soal nomor 3 karena berdasarkan hasil wawancara waktu telah habis. Pada tahap melakukan pengecekan kembali, merupakan tahap yang paling banyak siswa melakukan kesalahan dibandingkan dengan tahap yang lain. Hal tersebut disebabkan oleh tidak terbiasanya siswa dalam mengecek kembali jawaban yang telah diperoleh dan mereka tidak melakukan pengecekan jawaban karena sudah yakin dengan jawaban mereka, bahwa jawaban mereka sudah benar.

\subsubsection{Analisis Kesalahan Siswa Tingkat kemampuan Sedang}

\section{Subjek D33}

Subjek D33 memperoleh kategori tingkat kesalahan tinggi dengan jumlah skor kesalahan 59. Siswa hanya mampu menyelesaiakan soal nomor 3. Berdasarkan hasil pekerjaan subjek D33, Pada tahap memahami masalah siswa sudah tepat menuliskan apa yang diketahui dan apa yang ditanyakan dalam soal hanya untuk 
soal nomor 1 dan 3, sedangkan untuk soal nomor 2 siswa melakukan kesalahan dalam memahami masalah, berdasarkan hasil wawancara kesulitan yang dialami siswa pada soal nomor 2 ini adalah siswa sulit memahami apa yang diketahui dan ditanyakan dalam soal. Pada tahap menyusun rencana siswa hanya mampu membuat permisalan variabel untuk soal nomor 1, sedangkan dalam membuat model matematika siswa hanya melakukan untuk soal nomor 1 dan 3. Siswa tidak menuliskan metode apa yang digunakan serta tidak menuliskan langkah-langkah penyelesaian. Pada tahap melaksanakan rencana peneliti juga tidak menemukan kesesuaian penyelesaian dengan metode yang telah dipilih. Pada saat melakukan perhitungan untuk soal nomor 3 siswa hanya mendapatkan nilai dari panjang dan lebar saja sedangkan bukan panjang dan lebarnya saja yang diinginkan oleh soal melainkan luas. Siswa tidak memperoleh kesimpulan akhir dari semua soal yang kerjakan. Pada tahap melakukan pengecekan kembali siswa memeriksa solusi yang didapatkan namun belum tepat. Pada tahap menyusun rencana penyelesaian, siswa dengan tingkat kemampuan matematika sedang mampu menentukan kaitan antara apa yang diketahui dan ditanyakan yang selanjutnya subjek mampu membuat rencana pemecahan masalah untuk beberapa soal saja. Namun rencana pemecahan masalah yang dibuat masih belum tepat seperti salah dalam membuat permisalan ataupun dalam membuat model matematika. Hal itulah yang menyebabkan siswa berkemampuan sedang kurang dalam tahap menyusun rencana.

\section{Subjek A15}

Subjek A15 memperoleh kategori tingkat kesalahan tinggi dengan jumlah skor kesalahan 49. Siswa hanya mampu menyelesaikan soal nomor 1. Berdasarkan hasil pekerjaan subjek A15, Pada tahap memahami masalah siswa menuliskan apa yang diketahui dan apa yang ditanyakan dalam soal nomor 1 dan 2. Pada tahap menyusun rencana, siswa menuliskan permisalan variabel dan model matematika hanya untuk soal nomor 1saja, siswa tidak menuliskan metode serta langkahlangkah yang digunakan dalam menyelesaiakan soal. Pada tahap melaksanakan rencana peneliti tidak menemukan kesesuaian antara metode yang dipilih. Siswa melakukan perhitungan dengan benar dan runtut namun tidak menuliskan kesimpulan. Pada tahap melakukan pengecekan kembali siswa belum tepat melakukannya. Siswa sama sekali tidak mengerjakan soal nomor 3 setelah dilakukan wawancara ternyata menurut siswa, dia tidak mampu melanjutkan soal yang diberikan karena tidak sesuai dengan penjelasan yang dicontohkan.

\subsubsection{Analisis Kesalahan Siswa Tingkat kemampuan Rendah}

\section{Subjek A8}

Subjek A8 memperoleh kategori tingkat kesalahan tinggi dengan jumlah skor kesalahan 60. Berdasarkan hasil pekerjaan subjek A8, pada tahap memahami masalah siswa salah dalam menuliskan apa yang diketahui dan tidak menuliskan 
apa yang ditanya dalam soal nomor 1 . Pada tahap menyusun rencana siswa tidak menuliskan permisalan variabel namun hanya menuliskan model matematika, siswa tidak menuliskan metode dan langkah-langkah penyelesaian yang digunakan dalam menyelesaiakan soal. Pada tahap melaksanakan rencana siswa tidak memperoleh kesimpulan akhir. Siswa sama sekali tidak melakukan tahap pengecekan kembali. Ada beberapa siswa yang mampu memahami masalah tanpa menuliskan apa yang diketahui dan apa yang ditanyakan dari permasalahan. $\mathrm{S}$ iswa yang melakukan kesalahan tidak menuliskan hal-hal yang diketahui dan ditanyakan tetapi bisa menyelesaikan tahap selanjutnya tidak berarti siswa tersebut tidak memahami masalah yang diberikan melainkan siswa sudah terbiasa dalam menyelesaikan soal uraian dengan tidak menuliskan apa yang diketahui dan apa yang ditanyakan (Wati, Maria Kristofora dan Sujadi, 2017). Subjek A8 tidak dapat menyelesaikan 3 soal yang diberikan oleh peneliti.

\section{Subjek D15}

Subjek D15 memperoleh kategori tingkat kesalahan sangat tinggi dengan jumlah skor kesalahan 64 . Berdasarkan hasil pekerjaan subjek D15, siswa hanya mampu menuliskan apa yang diketahui untuk soal nomor 1 . subjek D15 sama sekali tidak mengerjakan soal nomor 3 dan 2 yang diberikan. Siswa tidak melakukan tahap menyusun rencana melaksanakan rencana dan melakukan pengecekan kembali. Siswa dikatakan memahami masalah jika siswa mampu mengemukakan data yang diketahui dan yang ditanyakan dari masalah yang diberikan (Sudarman, 2010). Pada tahap membuat rencana penyelesaian, siswa dengan tingkat kemampuan rendah tidak terbiasanya dalam menuliskan rencana penyelesaian yang akan mereka gunakan seperti tidak menuliskan model matematika yang digunakan untuk menyelesaikan suatu permasalahan. Kesalahan pada tahapan melaksanakan rencana yang dilakukan siswa terjadi karena pada tahapan sebelumnya siswa sudah melakukan kesalahan yang menyebabkan terjadinya kesalahan beruntun. Pencapaian utama dalam pemecahan masalah terletak pada gagasan rencana. Jika pada penyusunan rencana terjadi kesalahan maka pelaksanaannya juga akan salah (Polya, G., 1973). Untuk beberapa nomor, siswa tidak menuliskan permisalan dalam membuat model matematika. Penyebab siswa melakukan kesalahan menyusun rencana adalah karena siswa tidak terbiasa dalam menuliskan rencana yang digunakannya dalam menyelesaikan soal seperti: tidak menuliskan permisalan variabel yang akan digunakan dalam membuat model matematika (Hidayah, Shofia, 2016). Pada tahap melaksanakan rencana, siswa dengan tingkat kemampuan matematika rendah cenderung melaksanakan rencana pemecahan masalah dengan prosedur yang kurang tepat, sehingga salah dalam menentukan hasil akhir yang diminta soal. Faktor penyebab kesalahan dalam melakukan perhitungan menyelesaikan soal banyak dilakukan siswa ketika pengaturan waktu yang tidak sesuai dengan cara menyelesaikan soal membuat siswa panik dan tergesa- gesa dalam menuliskan jawaban sehingga membuat siswa tidak memeriksa hasil pekerjaannya. Kesalahan yang paling fatal dilakukan siswa pada tahapan menyusun rencana adalah kesalahan saat membuat model 
matematika. Kesalahan ini terjadi karena siswa kurang memahami materi prasyarat sehingga siswa tidak bisa membuat model matematika. Pada tahap menyusun rencana siswa harus dapat memikirkan langkah-langkah apa saja yang penting dan saling menunjang untuk dapat memecahkan masalah yang dihadapi [10]. Kemampuan berpikir yang tepat hanya dapat dilakukan jika siswa telah dibekali sebelumnya dengan pengetahuan-pengetahuan yang cukup memadai dalam arti masalah yang dihadapi siswa bukan hal baru sama sekali tetapi sejenis atau mendekati. Yang harus dilakukan siswa pada tahap ini adalah siswa dapat mencari konsep-konsep atau teori yang saling menunjang dan mencari rumusrumus yang diperlukan.

\subsection{Hubungan atau Korelasi Masing-Masing Kesalahan Berdasarkan Prosedur Polya}

Nilai koefisien korelasi jenis kesalahan memahami masalah dengan menyusun rencana adalah sebesar 0,55 menunjukkan bahwa hubungan antara jenis kesalahan memahami masalah dengan kesalahan menyusun rencana cukup kuat dan sumbangan korelasi sebesar 30,57\%. Selanjutnya untuk nilai koefisien korelasi jenis kesalahan memahami masalah dengan melaksanakan rencana adalah sebesar 0,49 menunjukkan bahwa hubungan antara jenis kesalahan memahami masalah dengan melaksanakan rencana cukup kuat dan sumbangan korelasi sebesar 24,67. kemudian untuk nilai koefisien korelasi jenis kesalahan memahami masalah dengan melakukan pengecekan kembali adalah sebesar 0,49 menunjukkan bahwa hubungan antara jenis kesalahan menyusun rencana dengan melaksanakan rencana cukup kuat dan sumbangan korelasi sebesar $24,67 \%$. Untuk nilai koefisien korelasi jenis kesalahan menyusun rencana rencana dengan melaksanakan rencana adalah sebesar 0,79 menunjukkan bahwa hubungan antara jenis kesalahan menyusun rencana masalah dengan melaksanakan rencana kuat dan sumbangan korelasi sebesar 63,56 \%. Untuk nilai koefisien korelasi jenis kesalahan menyususun rencana dengan melakukan pengecekan kembali adalah sebesar 0,69 menunjukkan bahwa hubungan antara jenis kesalahan menyusun rencana dengan melakukan pengecekan kembali kuat dan sumbangan korelasi sebesar 0,69 \% dan yang terakhir untuk nilai koefisien korelasi jenis kesalahan melaksanakan rencana dengan melakukan pengecekan kembali adalah sebesar 0,84 menunjukkan bahwa hubungan antara jenis kesalahan melaksanakan rencana dengan melakukan pengecekan kembali sangat kuat dan sumbangan korelasi sebesar 70,76 \%.

Setiap tahapan dalam pemecahan masalah menurut Polya berkaitan satu dengan yang lain. Jika siswa melalukan kesalahan pada tahap memahami masalah maka akan berpengaruh pada tahap-tahap selanjutnya. Misalnya hubungan antara tahap memahami masalah dengan tahap menyusun rencana memiliki hubungan yang cukup kuat artinya apabila siswa melakukan kesalahan pada tahap pemecahan masalah berarti akan ada kesalahan juga pada tahap menyusun rencana. Hal ini 
yang menyebabkan siswa melakukan kesalahan ketika dihadapkan dengan soal matematika berbentuk cerita.

Nilai korelasi yang berkisar antara 1 sampai -1, jika nilai semakin mendekati 1 atau -1 berarti hubungan antara dua variabel semakin kuat. Dikarenakan nilai koefisien pada analisa di atas seluruhnya positif yang berarti apabila nilai salah satu variabelnya naik, maka nilai variabel pasangannya juga akan naik. Begitu juga sebaliknya apabila nilai salah satu variabelnya turun, maka nilai variabel pasangannya juga akan turun.

\section{SIMPULAN}

Berdasarkan hasil penelitian dan pembahasan yang telah peneliti uraikan dan menyesuaikan dengan tujuan penelitian, maka dapat disimpulkan: (1) Kesalahan yang dilakukan masing-masing siswa bervariasi pada setiap tahapan penyelesaiannya, mulai dari kesalahan memahami masalah, kesalahan menyusun rencana, kesalahan melaksanakan rencana hingga kesalaha melakukan pengecekan kembali. Kesalahan siswa untuk tingkat kemampuan tinggi berkategori rendah, untuk tingkat kemampuan sedang berkategori tinggi dan untuk tingkat kemampuan rendah berkategori tinggi. (2) Hubungan jenis-jenis kesalahan berdasarkan prosedur Polya memiliki 3 tingkat hubungan yaitu cukup kuat, kuat dan sangat kuat. Tingkat hubungan cukup kuat untuk jenis kesalahan memahami masalah dengan menyususn rencana, kesalahan memahami masalah dengan melaksanakan rencana dan kesalahan memahami masalah dengan melakukan pengecekan kembali. Tingkat hubungan kuat untuk jenis kesalahan menyusun rencana dengan melaksanakan rencana dan kesalahan menyusun rencana dengan melakukan pengecekan kembali, yang terakhir adalah tingkat hubungan sangat kuat untuk jenis kesalahan melaksanakan rencana dengan melakukan pengecekan kembali.

\section{REFERENSI}

Herutomo, Rezky A. 2014. Analisis Kesalahan dan Miskonsepsi Siswa Kelas VIII Pada Materi Aljabar. Edusentris, Jurnal Ilmu Pendidikan dan Pengajaran. 1(2), hal. 134145 .

Hidayah, Shofia. (2016). Analisis Kesalahan Siswa Dalam Menyelesaikan Soal Cerita SPLDV Berdasakan Langkah Penyelesaian Polya. Prosiding Seminar Nasional Pendidikan Matematika Universitas Kanjuruhan Malang. Vol I.

Mahardhikawati, Ema., Mardiyana dan Rubono S. (2017). Analisis Kemampuan Pemecahan Masalah Berdasarkan Langkah-langkah Polya Pada Materi Turunan Fungsi Ditinjau dari Kecerdasan Logis-Matematis Siswa Kelas XI IPA SMA Negeri 7 Surakarta Tahun Ajaran 2013/2014. Jurnal Pendidikan Matematika dan Matematika (JPMM), 1(4), hal. 119-128.

Polya, G. (1973). How to solve it. New jersey : Princeton university press. 
Pusat Penilaian Pendidikan Kementerian Pendidikan dan Kebudayaan. (2019). Laporan Hasil Ujian Nasional website: www.puspendik.kemendikbud. go.id, diakses tanggal 29 Juni 2019.

Tabondo, Y.V. dan Sinaga, Y.R. (2014) Identifikasi dan Analisis Kesulitan Siswa Kelas IV Dalam Menyelesaiakan Soal Cerita Topik Pecahan,KPK,dan FPB, Prosiding Seminar Nasional dan Pendidikan Sains IX.Fakultas Sains Matematika,UKSW, 5(1), hal. 848.

Sudarman. (2010). Proses Berpikir Siswa SMP Berdasarkan Adversity Quotient (AQ) dalam Menyelesaikan Masalah Matematika. Surabaya: Universitas Negeri Surabaya.

Wati, Maria Kristofora dan Sujadi. (2017). Analisis Kesalahan Dalam Menyelesaikan Masalah Matematika Dengan Menggunakan Langkah Polya Siswa Kelas VII SMP. Jurnal PRISMA Universitas Suryakancana, 6(1), hal. 9-16. 